\title{
Kate Rousmaniere The Principal's Office: A Social History of the American School Principal
}

\author{
Albany: State University of NewYork Press, 2013. 197 pp.
}

\section{Thomas Fleming}

University of Victoria

Countless articles, books, dissertations, theses, and reports have examined various facets of the principal's working life since administrative study began in education more than a century ago. However, despite the legions of professors and students who have long comprised a vast industry that prepares principals in graduate schools across the United States, educational and social historians have generally ignored this large and important occupational group that consists currently of more than 115,000 members in America's public and private schools. ${ }^{1}$

According to Rousmaniere, historians have neglected the study of school principals because they have preferred "to focus on institutional and policy history at the central office level or on the social history of teachers, students, and communities" (1). "Principals," she argues, slipped "through the middle, seemingly neither players in policy development nor in the day-to-day life of the classroom" (1).

Other and more idiosyncratic reasons also explain historians' longstanding disinterest. "One reason why the history of all school principals has been largely ignored," Rousmaniere advises, is "that historians shared with others a personal predilection against school principals. In our own life history, many of us remember an aspiring teacher but we may remember the principal only for an unfortunate, and assuredly unfair, disciplinary encounter" (2). Small wonder that principals have been stereotyped as "one-dimensional functionaries, white men in dull coloured baggy suits who obediently completed administrative tasks and ordered others to be obedient to them" (2). So, too, Rousmaniere adds, "for women and people of colour, the principal is often a position not of us, and not attainable" (2).

Nevertheless, historical caricatures of principals are mostly undeserved, Rousmaniere maintains. The diverse roles principals have historically fulfilled have 
made them "the most complex and contradictory figures in the pantheon of educational leadership" (2) as they struggle to balance family and community demands with the economic and political realities of school bureaucracies. Beset by forces far beyond their control — including state legislatures, militant and intrusive teacher unions, dissatisfied parents and community leaders - it is not surprising that principals carry with them a sense of ambiguity and unease about who they are and what they do.

Within a world characterized by uncertainty and contradiction, Rousmaniere chronicles the evolution of the American public school principal's office "amid the conflicting external and internal pressures on the people who sat in that office" (3). The focal points of the principalship's history are assembled into six wellwritten and deftly-organized chapters: "Preceptors, Head Teachers, and Principal Teachers: School Leadership through the Late Nineteenth Century;" "The Making of the Principal's Office, 1890-1940;" “Outside the Principal's Office: Principals, Democratic Leadership, and Community Change;" "Cracks in the System: School Leadership, 1945-1980;" "Bearing the Burden: The School Principal and Civil Rights;" and, finally, "Instructional Leaders in High-Stakes Schools." Each chapter illustrates how pedagogical and organizational forces within schools intersect at particular times with a kaleidoscope of social, economic, and political forces to produce a new stage in the development of school leaders. Each chapter also examines how principals are shaped by vacillating forces of constancy and change, sometimes pulling them in new directions, sometimes pulling them back to their older traditions and responsibilities.

The first two chapters provide an "inside-out" view of the principalship as it emerged in the post-Revolutionary era by detailing how it gradually assumed greater form in private, parochial, and community schools during the first half of the nineteenth century when principal-teachers began to embody "the cultural authority of the school in a way that the individual teacher could not" (9). As the great crusade for common schools intensified during the century's second half, civic and social reformers assigned principals a far more intoxicating role in the command and control of what were often poorly coordinated and, at times, chaotic schools.

Rousmaniere skillfully portrays the principal's questionable influence and status in the ragtag world of late nineteenth-century schools, pointing out to good effect that a principal's role and reputation were highly dependent on circumstance and place. In some communities, principals were influential figures who managed several schools with the brawny authority of Scottish lords. Elsewhere, principals toiled as mere clerks, instructed by school boards to do little more than maintain children's attendance records.

In the next four chapters, the narrative is more broadly driven by an outside-in perspective that surveys the intellectual and political events influencing the course of public schooling throughout much of the twentieth century and, in turn, principals' work lives. Beginning with the great progressive campaign to remanufacture the central institutions of American life in the early days of the new century, Rousmaniere recounts how ideas about democratic administration and consensual management 
gripped American society and schools as the Great Depression deepened in the 1930s and threats from totalitarian regimes overseas mounted.

Rousmaniere then reviews the troubled state of educational leadership in the postWorld War II era, a period marked by sharp criticisms of the school's scholastic failings, waning confidence in public education, and the exile of females from principals' offices in the 1940s and 1950s. Movements for civil rights and school desegregation imposed new priorities for principals in the post-1960s era, as did state and national reform initiatives in the 1970s and 1980s. Since the 1990s, the principal's world has been transformed again in light of emerging parental and community lobbying for enhanced school choice, campaigns for "effective" schools, and accelerating political demands for high stakes testing.

Within the arc of these developments, Rousmaniere's treatments of women and minorities in the principal's office clearly stand out as high points in this narrative. Her discussions of "culturally responsive principals" (68) who mobilized community support for predominantly black schools in black neighbourhoods as early as the mid-1930s, along with her account of the politics that reshaped and, sometimes, derailed progressive reform efforts, are particularly enlightening. Rousmaniere likewise deserves credit for illustrating how a historically strong female presence in principals' offices (albeit in schools that were mostly small, elementary, and rural) was dismantled by various factors after 1945, including school consolidation movements, demobilization and the GI Bill, as well as initiatives to de-feminize schools.

Summing things up, this readable volume makes a strong historical case that principals, by virtue of their strategic position as middle managers in schools, have played "a central role in the development of American schooling" and that, because of their unique position as "the connecting link," between school systems, communities, and children, they have remained "literally at the front door of educational change" (152). Rousmaniere is also correct in asserting that the principal's office is the place where many "of our deepest questions about public education" (152) come in search of resolution.

Obviously, a volume as economical as this in length (152 pages of text) cannot address all things. But if Professor Rousmaniere should decide to extend this work at some point, or if someone else would like to take on the challenge, certain additions may be worth considering. For example, greater attention could be given to chronicling how principals saw themselves and their work over time. Granted, principals and teachers are notoriously poor diarists, letter writers, and record keepers. Nevertheless, in the interest of seeing the world from behind the principal's desk, social historians could make far greater use of interview data and oral histories, along with small commemorative histories often written by former teachers, principals, and students.

An enlarged historical study of principals could also allow greater investigation of work and status differences between elementary principals and the men and women who supervised America's great high schools in the early and mid-twentieth century, many of which were institutions of immense civic - and, indeed, architectural - prominence. Exploring in greater depth the intellectual, social, and cultural 
differences that have historically separated the worlds of elementary and secondary school principals might explain, among other things, some of the organizational disconnections that still hamper K-12 systems today.

\section{Notes}

1 Amy Bitterman, Rebecca Goldring, and Lucinda Gray, Characteristics of Public and Private Elementary and Secondary School Principals in the United States: Results from the 2011-2012 Schools and Staffing Survey (Washington: National Center for Education Statistics, 2013.) 